\title{
DISSOLVED OXYGEN MASS BALANCE IN AQUACULTURE PONDS
}

\author{
SAMIR AHMAD ALI*
}

\section{ABSTRACT:}

The prediction of dissolved oxygen in aquaculture ponds throughout the year is essential to the design and evaluatesthe potential aquaculture sites. A computer model has been developed to simulate dissolved oxygen in a fish pond. A short-term Dissolved Oxygen (DO) fluctuation of a fishpond was developed by using various simple equations and continuous measurement of DO, temperature and solar intensity. Numerical computation has been performed for a typical winter $\left(17^{\text {th }}\right.$ of January) and summer ( $17^{\text {th }}$ of July) days.

Results from model verification runs showed that the model performance was satisfactory with respect to aquaculture pond dissolved oxygen. The relative percentage of error (RPE) for the 24 hours of simulation was $0.2818 \%$ and the correlation coefficient between predicted and measured dissolved oxygen was 0.97. The predicteddissolved oxygen was fluctuated between -0.101 to $0.113 \mathrm{gO}_{2} \mathrm{~m}^{-3}$ lower and higher than the measured dissolved oxygen for most of the 24 hour simulation.

The predicted results indicate that DO is affected by weather variables, especially solar radiation.The dissolved oxygen $(D O)$ values ranged from 4.4 to $8.7 \mathrm{~g} \mathrm{~m}^{-3}$, where it reached the highest value (8.7) at 17:00 h, while it reached the lowest value (4.4) at 6:00 h.

The fish growth model results indicated that the total cycle time between the stocking and the harvesting is about 180-190 days during the summer months; compared with the total cycle time in natural setting is about 210-240 days.

\section{INTRODUCTION}

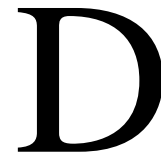
issolved Oxygen (DO) is one of the most important factors affecting most aquaculture species. For fish culture, maintaining dissolved oxygen at a level suitable for fish survival and growth does pond management. When DO levels in aquaculture ponds become

\footnotetext{
*Agric. Eng. Dept., Fac. Agric., Moshtohor, Toukh, Qalubia, P.O. Box, 13736, Egypt. Phone: +2 0132467034 Fax: +2 013246778

E-Mail samir.ali@ fagr.bu.edu.eg
} 
low, the cultured organisms may become stressed or even die. A healthy balance pond provides a fluctuation in oxygen levels between day and night that leaves an adequate concentration of oxygen in the water that can support aquatic animal life during both day and night hours. Phytoplankton can exert a profound effect on water quality constituents, especially dissolved oxygen, by producing supersaturated concentrations during the day and reduced levels during the night due to biotic respiration and chemical oxidants result in a net loss of oxygen which can reach critically low concentrations (Muhammetoglu and Soyupak, 2000). The highest oxygen levels in a pond are usually measured on sunny afternoon when phytoplankton and other aquatic plants are producing oxygen through photosynthesis. The lowest level occurs just before daybreak after a night of oxygen consumption by aquatic plants and animals. Dissolved oxygen consumption and regeneration by phytoplankton is directly related to their rates of photosynthesis and respiration.

The intensity of solar radiation strongly regulates rates of photosynthesis and oxygen evolution in fishponds (Romaire and Boyd, 1979). The rate of oxygen production is a function of the concentration of algae and other forcing functions. Because the growth of algae is light and temperature dependent, hence the rate of photosynthetic oxygen production follows the same pattern. Temperature is a parameter that shows a marked seasonal and daily variation in fishponds. It influences photosynthesis, growth of algae and bio decomposition of organic matter in the pond. Other factors such as density of fish, turbidity, organic matter levels and wind velocity also greatly influence dissolved oxygen budgets for fishponds (Boyd et al., 1978). In ponds showing marked stratification, surface waters may be harmful to fish due to supersaturated DO conditions in combination with high temperatures, while in the same pond near anoxic conditions may exist close to the bottom (Chang and Ouyang, 1988; Losordo, 1988; Boyd, 1990).

There are several reports of DO models incorporating mechanistic characterization of the chemical, physical and biological processes in an open pond which governs the resulting DO levels (Losordo, 1988; Losordo and Piedrahita, 1991). The intent of the present study describes 
to develop a dissolved oxygen model using input variables in low cost greenhouse fishpond. In this study additional modification have been implemented to the predictions of DO performance in greenhouse fishpond from calculation of solar radiation falling on greenhouse canopy cover to the pond water surface. This model simulates the hourly variation of DO in a fishpond over a $24 \mathrm{~h}$ period as influenced by the consumption and production of oxygen by phytoplankton and fish. Measurable rates of photosynthesis and respiration are needed for proper calibration of the model. This model is neither site nor species specific and input variables can be adjusted to accommodate most pond conditions. In freshwater fishponds effects of solar radiation on temperature and oxygen variations have been described in detail (Boyd, 1979). The model was developed with the following objectives under consideration:

- To determine components which have greatest effect on DO.

- To predict the DO concentration in aquaculture ponds.

\section{Model Development.}

\subsection{Dissolved oxygen model.}

The modeling of dissolved oxygen concentrations in an aquaculture pond depend upon some factors, which contributes oxygen entry into the pond, oxygen removal from the pond and oxygen exchanges within the pond. In a pond, dissolved oxygen concentrations depends on the balance between photosynthetic production, total respiration and exchanges with atmosphere (Eq. 2).

Two main hypotheses of the DO models are as follows:

- It is assumed that pond water is completely mixed.

- Biomasses and nutrients are supposed to be constant throughout the period during which the model is applied.

Under these two assumptions, the only state variable of the system is mean dissolved oxygen concentrations and the only forcing variables are solar intensity and temperature.

The solar radiation at the surface of the water attenuates through the water column. The effective light intensity in the water column directly affects the phytoplankton population, which in turn, increases dissolved 
oxygen during the day via photosynthesis and utilizes oxygen at night through respiration. Decaying phytoplankton, unconsumed fish feed and fish waste products also decrease DO as represented by sediment oxygen demand. The oxygen mass balance equations are specified by the program or calculated hourly over a $24 \mathrm{~h}$ period.

The rate of change in DO concentration in fishpond:

$$
\frac{d D O}{d t}=P-C \pm E
$$

$\mathrm{P}=\mathrm{DO}$ production, $\mathrm{C}=\mathrm{DO}$ Consumption, $\mathrm{E}=\mathrm{DO}$ Exchanges

$$
\begin{aligned}
\frac{d D O}{d t}=D O_{p h} & \pm D O_{s}-D O_{F R}-D O_{p r}-D O_{n r}-D O_{o m}-D O_{s e d} \\
& +D O_{i n}-D O_{0 u t}
\end{aligned}
$$

$\frac{d D O}{d t}=$ Rate of change in DO concentration during the time interval, $\mathrm{gm}^{-3} \mathrm{~h}^{-1}$.

$d t \quad=$ Rate of change in the time interval, $\mathrm{h}$

$D O_{p h}=$ Rate of photosynthetic production by phytoplankton, $\mathrm{g} \mathrm{m}^{-3} \mathrm{~h}^{-1}$.

$D O_{s}=$ Rate of reaeration at the water surface, $\mathrm{g} \mathrm{m}^{-3} \mathrm{~h}^{-1}$.

$D O_{F R}=$ Rate of DO respiration by fish, $\mathrm{g} \mathrm{m}^{-3} \mathrm{~h}^{-1}$.

$D O_{p r}=$ Rate of DO respiration by phytoplankton, $\mathrm{g} \mathrm{m}^{-3} \mathrm{~h}^{-1}$.

$D O_{n r}=$ Rate of DO consumption by nitrification, $\mathrm{g} \mathrm{m}^{-3} \mathrm{~h}^{-1}$.

$D O_{o m}=$ Rate of DO consumption by organic matter, $\mathrm{g} \mathrm{m}^{-3} \mathrm{~h}^{-1}$.

$D O_{\text {sed }}=$ Rate of DO consumption by sediment, $\mathrm{g} \mathrm{m}^{-1} \mathrm{~h}^{-1}$.

$D O_{\text {in }}=$ Rate of oxygen transfer with influent water, $\mathrm{g} \mathrm{m}^{-3} \mathrm{~h}^{-1}$.

$D O_{\text {out }}=$ Rate of oxygen transfer with effluent water, $\mathrm{g} \mathrm{m}^{-3} \mathrm{~h}^{-1}$.

After calculating oxygen concentration for each element at each time step, the net oxygen change is then added to or subtracted from the previous time step`s oxygen concentration. DO concentrations can be calculated at any time $(\mathrm{t})$ as:

$$
D O_{t}=D O_{t-1}+\left(\frac{d D O}{d t} \cdot d t\right)
$$

$\mathrm{DO}_{\mathrm{t}}=\mathrm{DO}$ concentration $\left(\mathrm{gm}^{-3}\right)$ at time $\mathrm{t}$

$\mathrm{DO}_{\mathrm{t}-1}=\mathrm{DO}$ concentration $\left(\mathrm{g} \mathrm{m}^{-3}\right)$ at time $\mathrm{t}-1$ 


\subsubsection{Dissolved Oxygen Production:}

\section{- Photosynthetic dissolved oxygen production}

In most aquaculture ponds phytoplankton provide the major source and sink for dissolved oxygen. Gross phytoplankton production rates are affected by many factors, including intensity of photosynthetically active radiation (PAR), light attenuation in the water column, water temperature.

Numerous expressions relating photosynthetic oxygen production are available (Eilers and Peeters, 1988). The rate of phytoplankton oxygen production can be calculated as (Smith, 1936 and Talling, 1957):

$$
D O_{p h}=\frac{P_{\max }}{K Z} \ln \left[\frac{E_{z}+\sqrt{\left(\frac{P_{\max }}{\alpha}\right)^{2}+E_{z}{ }^{2}}}{E_{z} \exp (-K Z)+\sqrt{\left(\frac{P_{\max }}{\alpha}\right)^{2}+\left(E_{z} \exp (-K Z)\right)^{2}}}\right]
$$

where:

$\mathrm{P}_{\max }=$ Maximum of DO production vs light curve $\left(\mathrm{g} \mathrm{O}_{2} \mathrm{~m}^{-3} \mathrm{~h}^{-1}\right)$

$\mathrm{E}_{\mathrm{z}} \quad=$ Light intensity at depth $\mathrm{Z}\left(\mathrm{Wm}^{-2}\right)$

$\mathrm{K} \quad=$ Light extinction coefficient $\left(\mathrm{m}^{-1}\right)$

$\mathrm{Z} \quad=$ Depth of water $(\mathrm{m})$

$\alpha=$ Initial slope of the DO production vs light carve $\left(\mathrm{g} \mathrm{O}_{2} \mathrm{~m}^{-3}\left(\mathrm{~W} \mathrm{~m}^{-2}\right)\right.$ $\left.\mathrm{h}^{-1}\right)$.

Light intensity within the water column can be evaluated by BeerLambert law, where the light intensity is attenuated exponentially with depth. The light extinction coefficient is influenced by the absorption and scattering of light within the water column dissolved and suspended substances of biological and non-biological.Light intensity can be calculated from relationship:

$$
E_{Z}=E_{t} e^{-K Z}
$$

$E_{t}=$ Total solar radiation at water surface $\left(\mathrm{Wm}^{-2}\right)$ 
The total solar radiation flux incident $\left(E_{t}\right)$ on a surface is the combination of the direct (subscript $D$ ), diffuse (subscript $d$ ) and ground-reflected (subscript $r$ ) irradiance of the surface which gives (ASHRAE, 2005):

$$
E_{t}=E_{D}+E_{d}+E_{r}
$$

The amount of solar irradiance is computed based on a number of solar angles and apparent solar time.

Apparent solar time (AST) is, in decimal hours:

$$
A S T=L S T+\frac{E T}{60}+\frac{L S M-L O N}{15}
$$

where:

LST = local standard time, decimal hours

ET = equation of time, decimal minutes

LSM = local standard time meridian, decimal degrees.

LON = local longitude, decimal degree.

The equation of time as taken from Duffie and Beckman (1991) is:

$$
\begin{aligned}
& \mathrm{ET}=229.2\left\{0.000075+0.001868 \cos \left[(\eta-1) \frac{360}{365}\right]\right. \\
& -0.032077 \sin [(\eta-1) 360 / 365] \\
& -0.014615 \cos 2[(\eta-1) 360 / 365] \\
& -0.04089 \sin 2[(\eta-1) 360 / 365]\}
\end{aligned}
$$

Where: $\eta$ is the number of the day from the first of January (where January $1^{\text {st }}$ is $\eta=1$ )

The solar altitude $(\beta)$ can be calculated as:

$$
\sin \beta=\cos L \cos \delta \cos H+\sin L \sin \delta
$$

Where:

$\mathrm{L}=$ latitude angle, degrees

$\delta=$ solar declination angle, degrees

$$
\delta=23.45 \sin \left\{\frac{[360(284-\eta)]}{365}\right\}
$$

$\mathrm{H}=$ solar hour angle, degrees

$$
H=15(A S T-12)
$$

The solar incident angle $(\theta)$ can be computed as:

$$
\cos \theta=\cos \beta \cos \gamma \sin \Sigma+\sin \beta \cos \Sigma
$$


Where:

$\Sigma=$ surface tilt angle from the horizontal plane, horizontal $=0^{\circ}$

$\gamma=$ surface-solar azimuth angle

$$
\gamma=\phi-\Psi
$$

$\varphi=$ solar azimuth angle

$$
\cos \phi=\frac{\sin \beta \sin L-\sin \delta}{\cos \beta \cos L}
$$

$\Psi=$ surface azimuth angle, degrees

Now the equations of solar irradiance are computed based on all of these angles in the following manner. The surface direct irradiance:

$$
\text { If } \cos \theta>0 \stackrel{\text { then }}{\longrightarrow} E_{D}=E_{D N} \cos \theta \stackrel{\text { otherwise }}{\longrightarrow} E_{D}=0
$$

And where ${ }_{\left(E_{D N}\right)}$ is the surface direct irradiance and is calculated as:

$$
\text { If } \beta>0 \stackrel{\text { then }}{\longrightarrow} E_{D N}=\frac{A}{\operatorname{EXP}(B / \sin \beta)} \stackrel{\text { otherwise }}{\longrightarrow} E_{D N}=0
$$

The diffuse irradiance $E_{d}$

For vertical surfaces

For surfaces other than vertical

$$
\begin{aligned}
& E_{d}=C Y E_{D N} \\
& E_{d}=C Y E_{D N} \frac{(1+\cos \Sigma)}{2}
\end{aligned}
$$

Where $\mathrm{Y}$ is the ratio of the sky diffuse irradiation on a vertical surfaces to the sky diffuse irradiation on a horizontal surfaces and

If $\cos (\theta)>-0.2 Y=0.55+0.437 \cos (\theta)+0.313 \cos ^{2}(\theta)$, otherwise $\mathrm{Y}=0.45$

Finally, the ground-reflected irradiance $E_{r}$ is computed as:

$$
E_{r}=E_{D N}\left(C_{n}+\sin \beta\right) \rho_{g}\left(\frac{1-\cos \Sigma}{2}\right)
$$

where:

$\mathrm{A}=$ apparent solar radiation, $\mathrm{W} \mathrm{m}^{-2}$

$$
=1147.5868+57.4985 \times \sin (0.0174 \times \eta+1.4782)
$$

$\mathrm{B}=$ atmospheric extinction coefficient

$$
=0.1639+0.0237 \times \sin (0.0202 \times \eta+4.013)
$$

$\mathrm{C}=$ sky diffuse factor

$$
=0.1207+0.0179 \times \sin (0.0203 \times \eta+3.9798)
$$


$\mathrm{C}_{\mathrm{n}}=$ clearness number

$\rho_{g}=$ ground reflectivity, often taken to be 0.2 for typical mixture of ground surfaces.

\section{- Reaeration:}

Water surface reaerationcan be either a source or a sink depending on the DO difference between the surface water and the air. A first order function is used to predict the reaeration rate (Culberson,1993):

$$
D O_{S}=K_{d o}\left(C_{s}-D O_{\text {surf }}\right) / Z
$$

where:

$\mathrm{K}_{\mathrm{do}}=$ oxygen transfer coefficient, $\mathrm{m} \mathrm{h}^{-1}$. It can be determined by (Banks and Herrera; 1977):

$$
K_{d o}=0.0036\left(8.43 \times W_{s}\right)^{0.5}-3.67 \times W_{s}+0.43 \times W_{s}^{2}
$$

$W_{s} \quad=$ wind speed at two meter above the water surface, $\mathrm{m} \mathrm{s}^{-1}$.

$C_{s} \quad=$ saturated $\mathrm{DO}$ in water at a given elevation and temperature, $\mathrm{g}$ $\mathrm{m}^{-3}$. It can be calculated by (Culberson, 1993):

$$
\begin{aligned}
C_{s}=(14.625 & \left.-0.41\left(T_{w}\right)+0.00799\left(T_{w}\right)^{2}-0.00778\left(T_{w}\right)^{3}\right) \\
& \times(1-0.0001 E)
\end{aligned}
$$

$E \quad=$ site elevation, $\mathrm{m}$.

$D O_{\text {surf }}=$ dissolved oxygen concentration for the surface layer, $\mathrm{g} \mathrm{m}^{-3}$.

$T_{w} \quad=$ water temperature, ${ }^{\circ} \mathrm{C}$.

\subsubsection{Dissolved oxygen Consumption:}

In an aquaculture pond after sunrise, DO increases due to photosynthesis, but at night, biotic respiration and chemical oxidants result in a net loss of oxygen, which can reach critically, low concentrations. Loss of oxygen from fishpond is due to fish respiration, plankton respiration, water column respiration and sediment respiration.

\section{- Fish Respiration}

The rate of oxygen consumption through fish respiration $\left(\mathrm{mg} \mathrm{O}_{2} \mathrm{~kg}^{-1} \mathrm{~h}^{-1}\right)$ can be calculated on water temperature and average fish weight. This calculation is shown in the following equation (Ali, 1999): 


$$
\begin{gathered}
F_{R}=2014.45+2.75 \times W_{n}-165.2 \times T_{w}+0.007 \times W_{n}^{2}+3.93 \\
\times T_{w}{ }^{2}-0.21 \times W_{n} \times T_{w} \\
D O_{F R}=F_{R} \times S_{D} / 1000
\end{gathered}
$$

where:

$F_{R} \quad=$ oxygen consumption through fish respiration $\mathrm{mg} \mathrm{O}_{2} \mathrm{~kg}^{-1} \mathrm{~h}^{-1}$,

$W_{n} \quad=$ average of individual fish weight, $\mathrm{g}$,

$S_{d} \quad=$ stocking density, $\mathrm{kg}_{\text {fish }} \mathrm{m}^{-3}$

\section{- Phytoplankton Respiration}

Respiration by phytoplankton and other microorganisms is a function of temperature as defined by Boyd et al. (1978):

$$
\begin{array}{r}
D O_{P R}=-1.133+0.0038 \times S D D+0.000014 \times S D D^{2}+0.081 \\
\times T_{w}-0.000749 \times T_{w}{ }^{2}-0.00035 \times S D D \times T_{w}
\end{array}
$$

$S D D=$ Secchi disc depth $(\mathrm{m})$

\section{- Nitrification:}

Ammonia concentration represents the total ammonia nitrogen (TAN) from fertilizers and fish wastes. Nitrification is a two steps process where ammonia is oxidized to nitrite and then to nitrate. The oxygen consumption in nitrification process can be calculated as (Lee et al., 1991):

$$
D O_{N R}=4.57 \times k_{N R} \times N r / V
$$

Where:

$4.57=$ stoichiometric coefficient for oxygen consumption in nitrification, $\mathrm{gO}_{2} \mathrm{gTAN}^{-1}$.

$$
k_{N R}=0.1(1.08)^{\left(T_{w}-20\right)}
$$

$\mathrm{Nr} \quad=$ nitrification rate, $\mathrm{gTAN} \mathrm{h}^{-1}$.

$$
N r=0.03 \times \frac{F_{r} \times W_{n} \times N_{F}}{24 \times 100}
$$

$F_{r}=$ Feeding Ratio, $\%$ of body fish day ${ }^{-1}$

The feeding ratio can be calculated as (Ali, 1999): 


$$
\left.F_{r}=17.02 \times e^{\left[\left(l N W_{n}+1.14\right)^{2} /\right.}-19.52\right]
$$

where:

$$
\begin{array}{ll}
N_{F} & =\text { No. of fish } \\
n & =\text { number of day from the start. }
\end{array}
$$

\section{- Oxidation of organic matter:}

The rate of oxidation of organic matter by bacteria is influenced by temperature and the function of temperature can be calculated as:

$$
D O_{o m}=\left[\frac{K_{o m}}{1000} \times \theta^{\left(T_{w}-T_{m}\right)}\right] / Z
$$

Where:

$K_{\text {om }}=$ oxidation of organic matter rate at reference temperature, $\mathrm{mg}$ $\mathrm{O}_{2} \mathrm{~m}^{-2} \mathrm{~h}^{-1}$.

$\theta=$ temperature correction factor, 1.047 (Tetra Tech, 1980).

$T_{m} \quad=$ reference temperature, $20^{\circ} \mathrm{C}$.

\section{- Sediment Respiration Rate:}

Although there are many factors affecting sediment respiration, sediment respiration is described by a simple function which includes the influence temperature (Jamu, 1998). The model is expressed as (Culberson, 1993):

$$
D O_{\text {sed }}=\left[\frac{K_{\text {sed }}}{1000} \times \theta^{\left(T_{w}-T_{m}\right)}\right] / Z
$$

where:

$K_{\text {sed }}=$ sediment respiration rate at reference temperature, $\mathrm{mg} \mathrm{O}_{2} \mathrm{~m}^{-2} \mathrm{~h}^{-1}$.

$\theta \quad=$ temperature correction factor, 1.065 (Culberson, 1993).

- Dissolved oxygen in the influent and effluent water.

The oxygen input to the surface layer is calculated as:

$$
D O_{\text {in }}=Q_{\text {in }} \times D O_{\text {inf }} / V
$$

where:

$D O_{\text {inf }}=$ DO concentration in the influent water, $\mathrm{g} \mathrm{m}^{-3}$.

$Q_{\text {in }} \quad=$ influent water discharge, $\mathrm{m}^{3} \mathrm{~h}^{-1}$.

$V \quad=$ water volume, $\mathrm{m}^{3}$.

The oxygen output in the effluent water can be calculated as:

$$
D O_{\text {out }}=Q_{\text {out }} \times D O_{\text {surf }} / V
$$

Where:

$\mathrm{DO}_{\text {surf }}=\mathrm{DO}$ concentration at the surface layer, $\mathrm{g} \mathrm{m}^{-3}$. 
Q $=$ eut $=$ efluent water discharge, $\mathrm{m}^{3} \mathrm{~h}^{-1}$.

\subsection{Fish growth model.}

The main objective for aquatic system is to increase the efficiency of fish growth. Fish growth is influenced not only by intrinsic factors such as fish size but also by a variety of environmental factors, including water temperature, photo-period, dissolved oxygen, unionized ammonia and food availability. These factors affect fish growth via their impacts on food consumption.

In order to calculate the daily growth rate "DGR" (g/day), for individual fish, the model developed by Yang Yi (1998) was used. It includes the main environmental factors influencing fish growth. Those factors are temperature, dissolved oxygen and unionized ammonia. The dissolved oxygen was generated from this model and the other water quality parameters was entered at the optimum levels for obtain the weight of individual fish throughout the year (Table 1).

$$
D G R=\left(0.2914 \tau \kappa \delta \varphi \mathrm{hf} W^{m}\right)-K W^{n}
$$

Where:

$$
\begin{array}{ll}
\tau & =\text { temperature factor }(0<\tau<1, \text { dimensionless }), \\
\kappa & =\text { photoperiod factor }(0<\kappa<1, \text { dimensionless }), \\
\delta & =\text { dissolved oxygen factor }(0<\delta<1, \text { dimensionless }), \\
\varphi & =\text { unionized ammonia (UIA) factor }(0<\varphi<1, \text { dimensionless }), \\
\mathrm{h} & =\text { coefficient of food consumption }\left(\mathrm{g}^{1-\mathrm{m}} \text { day }^{-1}\right), \\
\mathrm{f} & =\text { relative feeding level }(0<\mathrm{f}<1, \text { dimensionless }), \text { and } \\
\mathrm{K} & =\text { coefficient of catabolism. }
\end{array}
$$

Cuenco et al. (1985) reported that food consumption was not affected when DO was above a critical limit $\left(\mathrm{DO}_{\text {crit }}\right)$; $\mathrm{DO}_{\text {crit }}$ decreased more or less linearly with decreasing DO levels until a minimum level $\left(\mathrm{DO}_{\min }\right)$ was reached, below which fish would not feed. The function $(\delta)$ describing the effects of DO on food consumption was expressed by Bolte et al. (1995) as:

$$
\begin{aligned}
& \delta=1.0 \quad \text { if } \quad D O>D O_{\text {critical }} \\
& \delta=\frac{D O-D O_{\min }}{D O_{\text {critical }}-D O_{\min }} \quad \text { if } \quad D O_{\min } \leq D O \leq D O_{\text {critical }} \\
& \delta=0.0 \quad \text { if } \quad D O<D O_{\min }
\end{aligned}
$$


The $\mathrm{DO}_{\text {crit }}$ and $\mathrm{DO}_{\text {min }}$ used in the present model were 3.0 and $0.3 \mathrm{~g} \mathrm{~m}^{-3}$, respectively (Yang Yi, 1998).

Ursin (1967) assumed that the coefficient of catabolism (K) increases exponentially with temperature. Nath et al. (1994) modified this exponential from to include the minimum temperature (assumed to be equivalent to $\mathrm{T}_{\min }$ ) below which the fish cannot survive as follow:

$$
\mathrm{K}=\mathrm{k}_{\min } \operatorname{EXP}\left\{\mathrm{j}\left(\mathrm{T}-\mathrm{T}_{\min }\right)\right\}
$$

Where: $k_{\min }$ is the coefficient of fasting catabolism $\left(g^{1-n}\right.$ day $\left.{ }^{-1}\right)$ at $T_{\min }$, andj is the constant to describe temperature effects on catabolism.

Nath et al. (1994) used data on fasting Nile tilapia from Satoh et al. (1984) to estimate $\mathrm{k}_{\min }$ and $\mathrm{j}$ to be 0.00133 and 0.0132 , respectively.

The value of parameters ' $h$ ', ' $n$ ' and ' $m$ ' were assumed to be 0.80 (Bolte et al., 1995), 0.81 (Nath et al., 1994) and 0.67 (Ursin, 1967), respectively. Table (1): Parameters used in Yang Yi model.

\begin{tabular}{|l|c|l|}
\hline Parameter & Value & Reference \\
\hline Photoperiod factor $(\kappa)$ & 1.0 & Caulton (1982) \\
\hline Temperature factor $(\tau)$ & 1.0 & $\begin{array}{l}\text { Cuenco et al. (1985) } \\
\text { Bolte et al. (1995) } \\
\text { (Yang Yi, 1998) }\end{array}$ \\
\hline Unionized ammonia factor $(\varphi)$ & 1.0 & $\begin{array}{l}\text { Colt and Armstrong (1981) } \\
\text { Cuenco et al. (1985) } \\
\text { Bolte et al. (1995) } \\
\text { Abdalla (1989) }\end{array}$ \\
\hline Coefficient of food consumption (h) & 0.81 & Bolte et al., (1995) \\
\hline Relative feeding level (f) & 0.37 & Racoky, (1989) \\
\hline
\end{tabular}

Equation (34) is used to predict the daily growth rate. Equation (36) is used to calculate the accumulate growth starting by one gram of individual fish to the marketable weight of 250 grams.

$$
\mathrm{W}_{\mathrm{n}}=\mathrm{W}_{\mathrm{n}-1}+\mathrm{DGR}_{\mathrm{n}}
$$

\section{Model Validation.}

The developed dissolved oxygen model has been solved with the help of a computer program based on Excel software. To verify the accuracy of the developed model, experimental validations were conducted for a typical winter and summer days, $17^{\text {th }}$ of January and $17^{\text {th }}$ of July. The hourly variation of total solar radiation, dissolved oxygen, phytoplankton concentrations, temperature and secchi disc depth were used as inputs to calibrate the DO model. The coefficients and constants were used during model calibration are presented in Table 2 . 
Table 2:Model parameters used for computation:

\begin{tabular}{|c|c|c|c|}
\hline Parameters & Value & Unit & Reference \\
\hline Latitude & 28.4 & degree & This study \\
\hline Longitude & 30.0 & degree & This study \\
\hline Area $\left(A_{p}\right)$ & 400 & $\mathrm{~m}^{2}$ & This study \\
\hline Depth $(Z)$ & 1.0 & $\mathrm{~m}$ & This study \\
\hline No. of fish & 1600 & No. & This study \\
\hline $\begin{array}{l}\text { Weight of } \\
\text { individual fish, } \mathrm{W}\end{array}$ & $1.0-250$ & $\mathrm{~g}$ & This study \\
\hline $\mathrm{DO}_{\text {surf }}$ & 6.0 & $\mathrm{~g} \mathrm{~m}^{-3}$ & This study \\
\hline SDD & 0.37 & $\mathrm{M}$ & This study \\
\hline Initial slope $(\alpha)$ & 0.0081 & $\mathrm{gO}_{2} \mathrm{~m}^{-3}\left(\mathrm{~W} \mathrm{~m}^{-2}\right) \mathrm{h}^{-1}$ & Smith, 1936\&Talling, 1957 \\
\hline K & 0.86 & $\mathrm{~m}^{-1}$ & Smith, 1936\&Talling,1957 \\
\hline $\mathrm{P}_{\max }$ & 0.72 & $\mathrm{gO}_{2} \mathrm{~m}^{-3} \mathrm{~h}^{-1}$ & Smith, 1936\&Talling, 1957 \\
\hline $\mathrm{T}_{\mathrm{w}}$ & 28 & & This study \\
\hline Wind speed & $\mathrm{N}$ & $\mathrm{m} \mathrm{s}^{-1}$ & This study \\
\hline Initial DO & 6.0 & $\mathrm{~g} \mathrm{~m}^{-3}$ & This study \\
\hline $\mathrm{K}_{\mathrm{om}}$ & $1.08-3.00$ & $\mathrm{mg} \mathrm{m}^{-2} \mathrm{~h}^{-1}$ & $\begin{array}{c}\text { Jorgensen \&Gromiec, } 1989 \\
\text { Schroeder, } 1987 \\
\end{array}$ \\
\hline $\mathrm{K}_{\mathrm{sed}}$ & $0.005-0.01$ & $\mathrm{mg} \mathrm{m}^{-2} \mathrm{~h}^{-1}$ & Jamu, 1998 \\
\hline
\end{tabular}

\subsection{Solar Radiation:}

The equations describing solar radiation are based in theoretical and experimental basis and it has been applied to calculate total solar radiation falling on fishpond water surface.

To verify the accuracy of the developed model, daily average global solar radiation data measured on the horizontal surface is compared with that theoretically computed on the same surfaces for the day average of typical winter $\left(17^{\text {th }}\right.$, January) day as revealed in figure (1), and summer $\left(17^{\text {th }}\right.$, July) day as shown in figure (2). It is observed that both the set of values are closely matched indicating that the developed model is validated well.

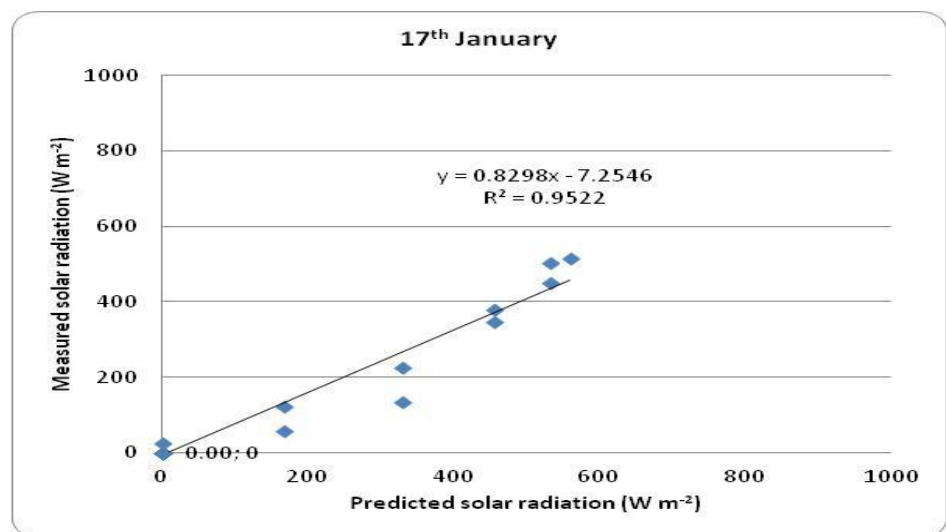

Fig.(1): Linear regression analysis of measured and predicted model solar radiationfor the average day of January month. 


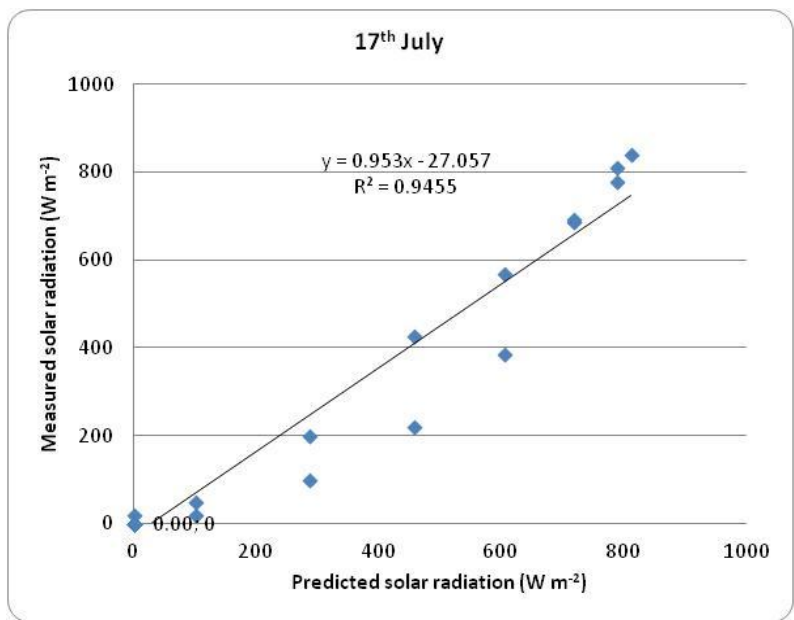

Fig. (2): Linear regression analysis of measured and predicted model solar radiation for the average day of July month.

\subsection{Dissolved Oxygen.}

The model runs utilizing input data from a $400 \mathrm{~m}^{2}$ tilapia production ponds at the World Fish Center, Regional Center for Africa and West Asia, Abbassa, AbouHammad, Sharkia, Egypt on typical summer $\left(17^{\text {th }}\right.$ of July) day. The available data at this center were air temperature, wind speed and direction and water pond temperature recorded every five minutes. The model uses the first two parameters to predict water pond dissolved oxygen were compared to the measured values for model validation.

Correlation, Regression and Relative Percentage of Error, RPE, [(Actual - Prediction)/Actual, El-Haddad, 1977] were used as indicators of the level of agreement degree between the predicted and measured values.

The simulated dissolved oxygen was fluctuated between -0.101 to $0.113 \mathrm{gO}_{2} \mathrm{~m}^{-3}$ lower and higher than the measured dissolved oxygen for most of the 24-hour simulation (Figure 5). The RPE for the 24 hours of simulation was $0.2818 \%$ and the correlation coefficient between simulated and measured dissolved oxygen was 0.97 . 


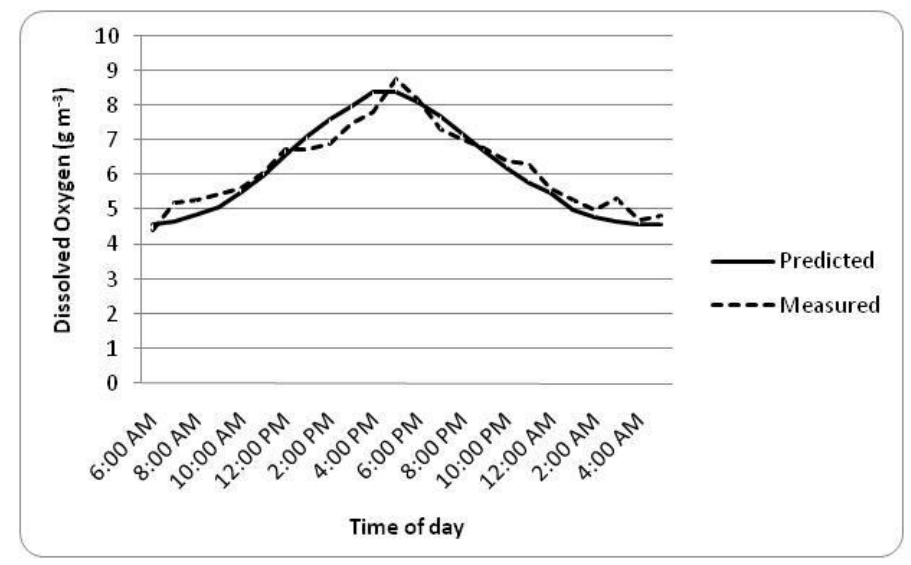

Figure (4): Measured and predicted dissolved oxygen.

The pond DO concentration was positively correlated with solar radiation and maximum production was at higher solar intensity. It increases as the phytoplankton produces more oxygen through photosynthesis than is consumed through respiration and decay. The phytoplankton photosynthesis decreases as the intensity of the solar radiation decreases in the late afternoon. Algae respond to the daily solar radiation and will reach their maximum rate of photosynthesis at a light intensity, which is a function of the daily solar radiation (Iohimura, 1960).

From the Fig. 4, it is noted that the DO reaches its maximum between 13:00 to 15:00 of sunshine hours, while the minimum values were observed at dawn. The hourly predictions of DO concentrations are close to the experimental values. The predicted DO exhibited agreement with the values of coefficient of correlation $r=0.97$. In the morning hours the pond DO is falling due to the phytoplankton, fish respiration.Regression analysis was carried out between the measured and predicted DO, and the most appropriate form in the following equation:

\section{Predicted $D O=1.046+0.837 \times$ Measured $D O$}

The model output has correlation with the experimental data at a determination coefficient of (0.943). Such an agreement of the predicted model data and that of the actual experimental data indicate that the rates and constants used in the development of the model are valid for a description of the processes of utilization and production of DO (Fig. 5). 


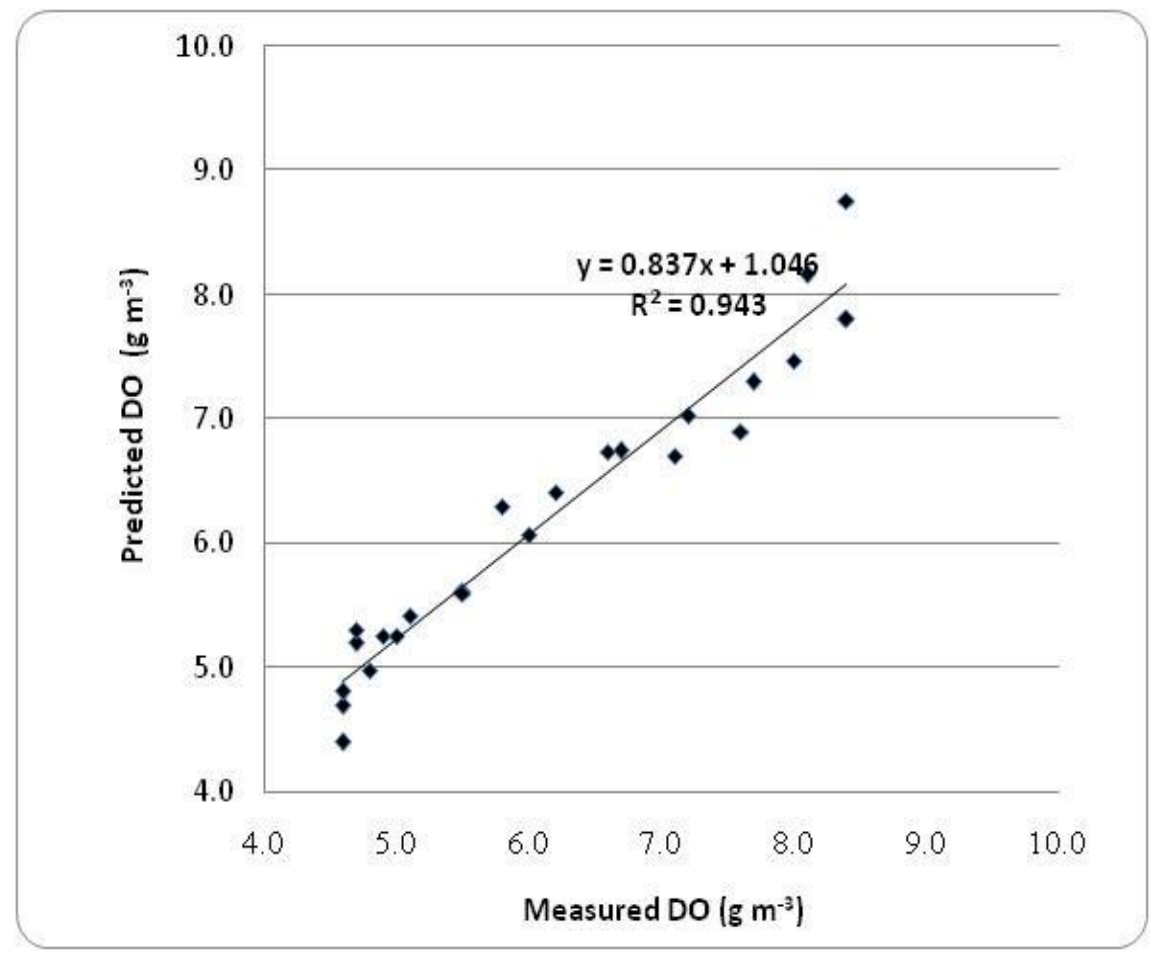

Fig.(5):Linear regression analysis of measured and predicted model DO for fishpond.

\section{Model Application.}

\subsection{Oxygen production.}

From the Fig. 4 it is seen that maximum solar radiationoccurs at 12.00$13.00 \mathrm{~h}$. The photosynthetic oxygen production is plotted against intensity of photosynthetically active radiation(PAR) of the pond during sunshine hours in Fig. 6.Regression analysis was carried out between the photosynthetic oxygen production and the intensity of photosynthetically active radiation(PAR), and the most appropriate form in the following equation:

Photosynthetic oxygen production $=-0.642+0.239 L N(P A R)$ 


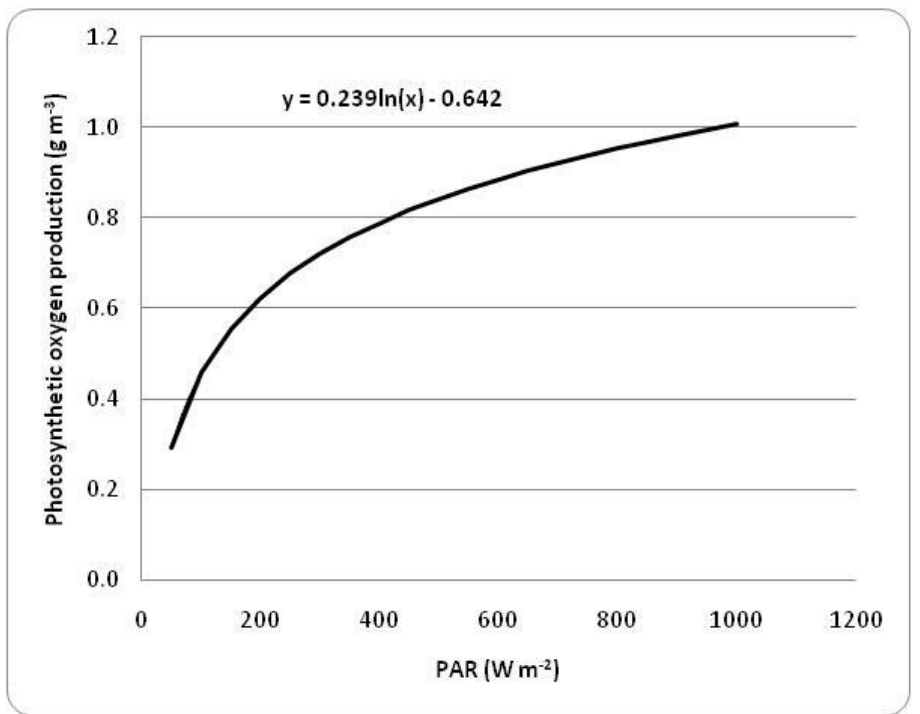

Fig. (6): Relation between photosynthetic oxygen production and photoactive solar radiation (PAR, $\mathrm{W} \mathrm{m}^{-2}$ ) during sunshine hours

\subsection{Fish Growth:}

Figure (7) shows the hourly weight gain $\left(\mathrm{gh}^{-1}\right)$ and weights of individual fish $(\mathrm{g})$ versus growing period $(\mathrm{h})$. The results indicated that the total cycle time between the stocking and the harvesting is about 180-190 days; compared with the total cycle time in natural setting is about 210240 days. These differences were probably due to differences in water quality with respect to both dissolved oxygen and total ammonia nitrogen.

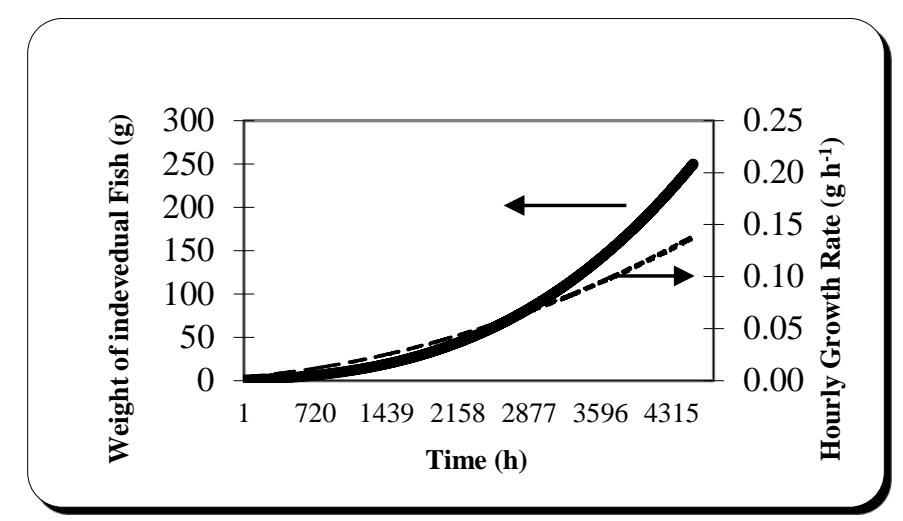

Figure (7): The weight of individual fish (g) and hourly weight gain $\left(\mathrm{gh}^{-1}\right)$ versus growing period (h) at temperature $28^{\circ} \mathrm{C}$ and unionized ammonia $<0.06 \mathrm{~g} \mathrm{~m}^{-3}$. 


\section{CONCLUSIONS:}

A mass balance of the dissolved oxygen in $400 \mathrm{~m}^{3}$ earthen aquaculture ponds was carried out considering the factors affecting it such as temperature and solar intensity.

Components considered in the DO model include the production of DO by phytoplankton and reaerationand consumption of oxygen by phytoplankton, fish, organic matter, nitrification and sediment. Numerical equations were solved with computer model to predict DO in the pond. The amount and distribution of oxygen production in the water column depend on solar intensity and penetration as well as phytoplankton concentration.

The predicted results indicate that DO is affected by weather variables, especially solar radiation. The dissolved oxygen (DO) values ranged from 4.4 to $8.7 \mathrm{~g} \mathrm{~m}^{-3}$, where it reached the highest value (8.7) at 17:00 h, while it reached the lowest value (4.4) at 6:00 h.

Results from model verification runs showed that the model performance was satisfactory with respect to aquaculture pond dissolved oxygen. The relative percentage of error (RPE) for the 24 hours of simulation was $0.2818 \%$ and the correlation coefficient between predicted and measured dissolved oxygen was 0.97. The predicteddissolved oxygen was fluctuated between -0.101 to $0.113 \mathrm{gO}_{2} \mathrm{~m}^{-3}$ lower and higher than the measured dissolved oxygen for most of the 24 hour simulation.

The fish growth model results indicated that the total cycle time between the stocking and the harvesting is about 180-190 days during the summer months; compared with the total cycle time in natural setting is about 210-240 days.

\section{REFERENCES:}

Abdalla, A.A.F. 1989. The Effect of Ammonia on Nile tilapia and its Dynamics and Fertilized Tropical Fish ponds. Ph.D. dissertation.Michigan State University, East Lansing, MI. 
Ali, S. A. (1999). Study of some engineering and environmental parameters on fish production in tanks. Ph. D., Thesis, Fac. Agric., Moshtohor, Zagazige Univ., Egypt.

Ali, S.A. and Z.A. El-Haddad.(1999). Simulation Model for Intensive Fish Farming, Misr Journal of Agricultural Engineering. Special Issue, $7^{\text {th }}$ Conference of Misr Society, 27-28 October.

ASHRAE (2005) "American Society of Heating, Refrigerating, and Air Conditioning Engineers" ASHREA Handbooks,Fundamentals.

Bolte, J.P., S.S. Nath and D.E. Ernst. 1995. POND: a decision support system for pond aquaculture, In: Egna, H.S., J. Bowman, B. Goetze\& N. Weidner. (Eds.), Twelve Annual Technical Report, Pond Dynamics/Aquaculture CRSP, Oregon State University, Corvallis, OR, pp. 48-67.

Boyd, C.E., 1979. Water Quality in Warm Water Fish Ponds. 1st Edn., Craft Master Printers, Albama.

Boyd, C.E., 1990. Water Quality in Ponds for Aquaculture. 1st Edn., Auburn University Agricultural Experimentation Station, Auburn, AL., Pages: 482.

Boyd, C.E., R.P. Romaire and E. Johnston, 1978.Predicting early morning dissolved oxygen concentrations in channel catfish ponds. Trans. Am. Fish. Soc., 107: 488-492.

Caulton, M.S. 1982. Feeding, metabolism and growth of tilapia: som quantitative considerations. In: R.S.V. Pullin\& R.H. McConnell (Eds.), The Biology and Culture of Tilapias. ICLARM Conference proccedings 7, 2-5 September 1980, Bellagio, Italy. International Center for Living Aquatic Resources Management, Manila, Philippines, 119-128. 
Chang, W.Y.B. and H. Ouyang, 1988.Dynamics of dissolved oxygen and vertical circulation in fish ponds. Aquaculture, 74: 263-276.

Colt, J. and D.A. Armstrong. 1981. Nitrogen toxicity to crustaceans, fish and molluscs. Procceding of the Bio-Engineering Symposium for Fish Culture, Bethesda, MD: American Fisheries Society.

Cuenco, M.L., R.R. Stickney and W.E. Grant. 1985. Fish bioenergetic and growth in aquaculture Ponds: III. Effects of intraspecific competition, stocking rate, stocking size and feeding rate on fish productivity.Ecological Modeling, 28: 73-95.

Culberson, S.D. 1993. Simplified model for prediction of temperature and dissolved oxygen in aquaculture pond: using reduced data inputs. M.S. Thesis. University of California, Davis.212 pp.

Duffie, J. A., Beckman, W. A., (1991)"Solar engineering of thermal processes" 2nd ed., John Wiley and Sons, New York, USA.

Eilers, P.H.C. and J.C.H. Peeters, 1988.A model for the relationship between light intensity and the rate of photosynthesis in phytoplankton. Ecol. Model., 42: 199-215.

El-Haddad, Z.A. 1977. Development a computer-based simulator for the management of a beef enterprise. Ph.D. Thesis in Agricultural Engineering, University of Newcastle Upon Tyne, England.

Ghosh, L., G.N. Tiwari and G.S. Sandhu, 2007.Design and construction of low cost aquaculture greenhouse. Proceeding of 3rd International Conference on Solar Radiation and Day Lighting (SOLARIS), February 7-9, New Delhi, India, pp: 274-278.

Iohimura, S., 1960.Diurnal fluctuations of chlorophyll content in lake water. Bot. Mag. Tokyo, 73: 217-224.

Jamu, D.M., 1998. Modeling organic matter and nitrogen dynamics in integrated aquaculture/agriculture systems: effects of cycling 
BIOLOGICAL ENGINEERING

pathways on nitrogen retention and system productivity.Ph.D.dissertation.297 pp.

Jorgensen, S.E. and M.J. Gromiec. 1989. Mathematical submodels in water quality systems. New York, NY, USA Elsevier science Pub. 409 pp.

Lee, J.H.W., R.S.S. Wu and Y.K. Cheung. 1991. Forecasting of dissolved oxygen in marine fish culture zone. Journal of environmental engineering. Vol. 117, No. 6: 816-833.

Losordo, T.M. and R.H. Piedrahita. 1991.Modelling temperature variation and thermal stratification in shallow aquaculture ponds. Ecol. Modell. 54, 189-226.

Losordo, T.M., 1988. The characterization and modeling of thermal and dissolved oxygen stratification in shallow aquaculture ponds. Ph.D. Thesis. University of California at Davis, pp: 416.

Muhammetoglu, A. and S. Soyupak, 2000.A three-dimensional water quality macrophyte interaction model for shallow lakes. Ecol. Model., 133: 161-180.

Nath, S.S., J.P. Bolte, D.H. Ernst and J.E. Lannan. 1994.Decision support systems pond aquacultre. In: Egna, H.S., J. Bowman, B. Goetze\& N. Weidner (eds.), Eleventh Annual Administrative Report, Pond Dynamics/Aquacultre CRSP. Oregon State University, Corvallis, OR, 108-124.

Rakocy, J.E. 1989. Tank culture of tilapia.InThe Biology and Culture of Tilapias, ed. R.S.V. Pullin\& R.H. Lowe-McConell.ICLARM Conference Proceedings 7. International Center for Living Aquatic Resources Management, Manila, The Philippines. 
Romaire, R.P. and C.E. Boyd, 1979.Effects of solar radiation on the dynamics of dissolved oxygen in channel catfish ponds. Trans. Am. Fish Soc., 108: 473-480.

Satoh, S., T. Takeuchi and T. Watanabe. 1984. Effects of starvation and environmental temperature on proximate and fatty acid composition of Tilapia nilotica.Bulletin of the Japanese Society of Scintific Fisheries, 50: 79-84.

Schoerder, G.L. 1987. Carbon and Nitrogen budgets in manured fish ponds on Israel's coastal plain. Aquaculture, 62: 259-279.

Smith, E.L., 1936. Photosynthesis in relation to light and carbondioxide. Nat. Acad. Sci. Proc., 22: 504-511.

Talling, J.F., 1957. Photosynthetic characteristics of some freshwater plankton diatoms in relation to underwater radiation. New Phytol., 56: 29-50.

Tetra.Tech. Inc. 1980.Methodolgy of Evaluation of Multiple Power Plant Cooling System Effects. V. Method Application to Prototype Cayuga Lake. Tetra Tech. Inc. Lafayette, Califonia. Report EPRI EA-III.

Tiwari, G.N., B. Sarkar and L. Ghosh, 2006.Observations of common carp (Cyprinuscarpio) fry-fingerlings rearing in a greenhouse during winter period. Agric. Eng. Int. CIGRE J. Manuscript, 7: 117.

Ursin, E. 1967.A mathematical model of some aspects of fish growth, respiration and mortality.Journal of the Fisheries Research Board of Canada, 24: 2355-2453.

Yang, Yi. 1998. A bioenergetics growth model for Nile tilapia (Oreochromisniloticus) based on limiting nutrients and fish standing crop in fertilized pond. Aquacultural Engineering, 18: 157-173. 


\section{الملخص العربى \\ إتزان كتلي للأكسجين الذائب فى أحواض الزراعة المائية

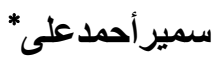

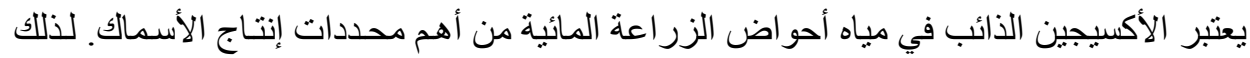

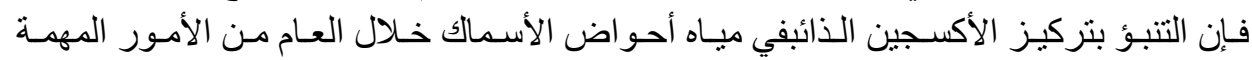
لتصميم وتخطيط الزر اعات المائية.

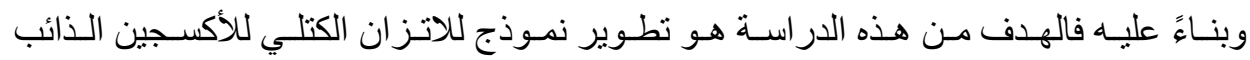

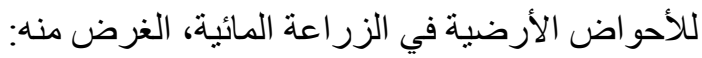

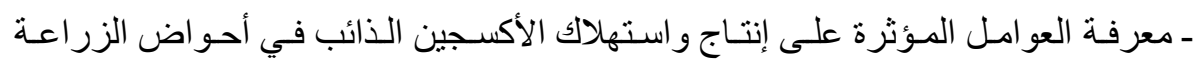

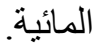

ـ التنبؤ بتركيز الأكسجين الذائب فيمياه تلك الأحو اض.

ولهذا الغرض تم بناء برنامج حاسب آلي لحل المعادلة التفاضلية التالية:

$\begin{aligned} \frac{d D O}{d t}=D O_{p h} & \pm D O_{s}-D O_{F R}-D O_{p r}-D O_{n r}-D O_{o m}-D O_{s e d}+D O_{i n} \\ & -D O_{0 u t}\end{aligned}$

= معدل التغير في تركيز الأكسجين الذائب عند وقت الحساب (جم أكسجينم-" ساعة")،

= $=d t$

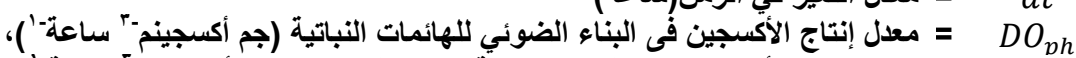

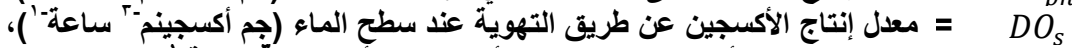

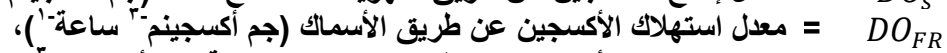

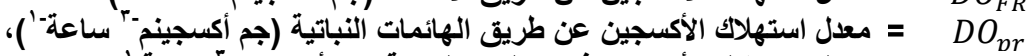

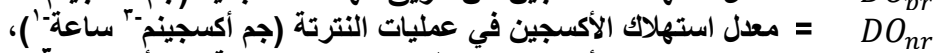
= $=0 O_{o m}$

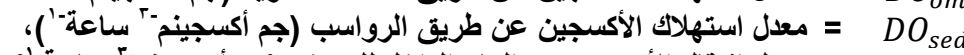

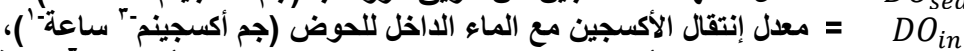

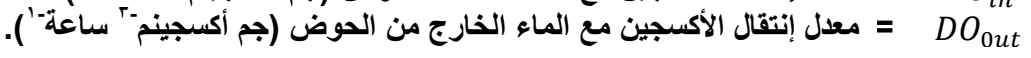
يلي ذلك حساب تركيز الأكسجين الأيائب عند وقت ما كما يلي:

$$
D O_{t}=D O_{t-1}+\left(\frac{d D O}{d t} \cdot d t\right)
$$

حيث: DO = تركيز الأكسجين الذائب عند وقت ما $t$ (جم أكسجين م-")،

*ناذ الهندسة الزراعية المساعد - كلية الزراعةـ جامعة بنها 


$$
\begin{aligned}
& \text { = معدل التغير في تركيز الأكسجين الذائب عند وقت ما t(جم أكسجين مَّ)، }
\end{aligned}
$$

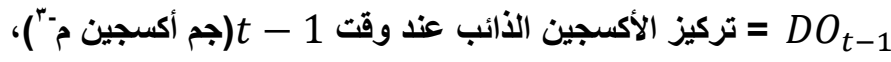

استخدمت بيانات المناخ المأخوذة من خلال محطة الأرصساد بـالمركز الدولي للأسماك بالعباسـة

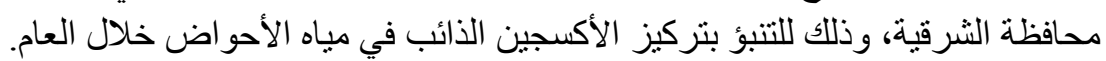

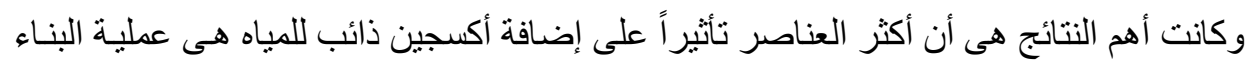

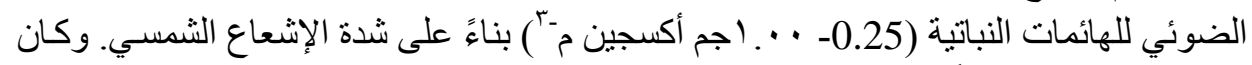
أكثر العناصر إستهلاكاً للأكسجين هو تنفس الأسماك.

بعد ذللك تم تجريب النموذج باستخدام تركيز الأكسجين الذائب المتنبأ به في النمودج الحسالي في

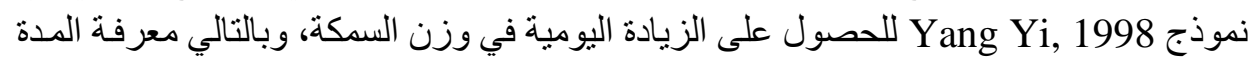

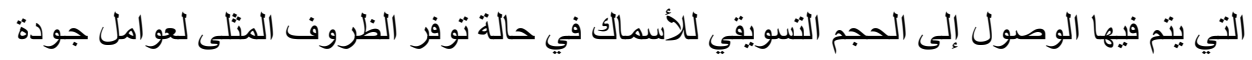

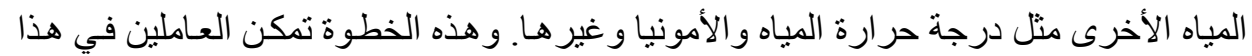
المجال بعمل استر اتيجية للانتاج طو ال العام.وكانت أهم النتائج كما يلي:

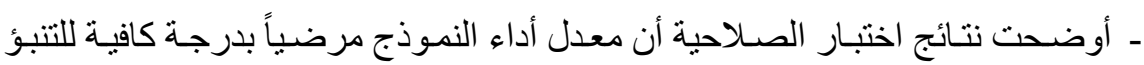

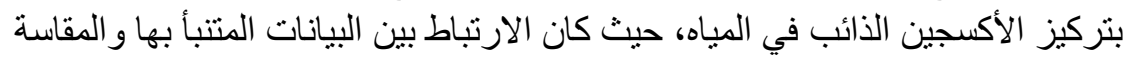

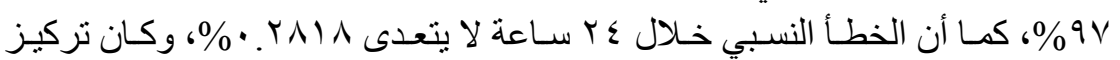

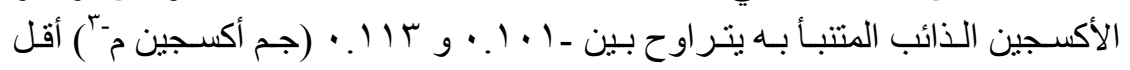

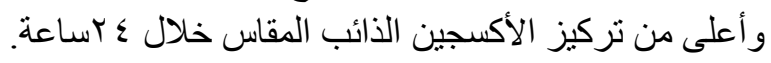

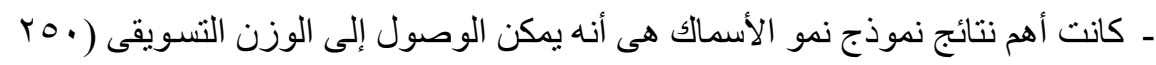

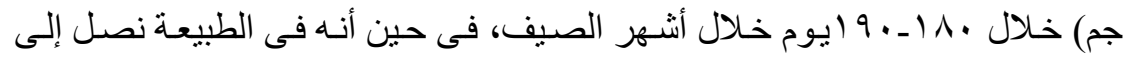

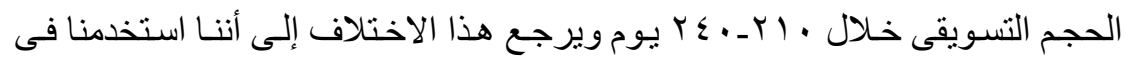

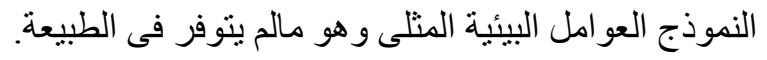

